\title{
Building gardens, rebuilding a city: Baltimore's Community Greening Resource Network
}

\author{
Sarah Krones, Parks \& People Foundation, Baltimore, Maryland $d^{\mathrm{a} b}$ \\ Shari Edelson, Parks \& People Foundation, Baltimore, Maryland ${ }^{\mathrm{C}}$
}

Submitted 21 July 2010 / Accepted 13 March 2011 / Published online 28 April 2011

Citation: Krones, S., \& Edelson, S. (2011). Building gardens, rebuilding a city: Baltimore's Community Greening

Resource Network. Journal of Agriculture, Food Systems, and Community Development, 1(3), 133-149.

http://dx.doi.org/10.5304/jafscd.2011.013.005

Copyright (C) 2011 by New Leaf Associates, Inc.

\begin{abstract}
Vacant spaces in urban areas are agents of blight and are prevalent in impoverished neighborhoods with high incidences of food insecurity. However, residents in many cities are reclaiming such spaces and converting them into community assets by installing community gardens. This article describes a program in Baltimore, Maryland, that has enabled low-income citizens to become involved in gardening. Modeled after Detroit's Garden Resource Program Collaborative, Baltimore's Community Greening Resource Network (CGRN) provides gardening resources and materials by coordinating

a Corresponding author: 800 Wyman Park Drive, Suite 010, Baltimore, MD 21211 USA; tel. +1-301-788-2698; kroness@gmail.com

b Permanent address: 2329A Oak Drive, Ijamsville, MD 21754 USA

c 800 Wyman Park Drive, Suite 010, Baltimore, MD 21211

USA; tel. +1-410-448-5663 ext. 114;

shari.edelson@parksandpeople.org

In the interest of full disclosure, the authors note that they are or were employed by the Parks \& People Foundation during the writing of this report. They received no additional compensation for their research.
\end{abstract}

the efforts of multiple partner organizations. By making such resources readily available, CGRN removes barriers that otherwise discourage residents from reclaiming open spaces. In this tangible way, CGRN empowers low-income residents to actively revitalize their own communities. Since its development in 2008, CGRN has served an everincreasing membership, delivering resources to a steadily expanding community of urban gardeners. Despite these successes, challenges remain with respect to funding and staff retention. Our experience replicating the resource network model from Detroit to Baltimore can provide guidance for other groups interested in implementing similar programs.

\section{Keywords}

Baltimore, collaboration, community garden, food security, revitalization, urban

\section{Introduction}

Community gardens are emerging in postindustrial cities across the United States. Studies have shown the significant role that green spaces, particularly in 
the form of urban agriculture and urban gardening, can play in food security and community renewal. As Brown and Carter (2003, p. 3) note, "economic development and community revitalization are achieved when neighborhoods take pride in a community garden [and] when inner-city residents gain the ability to grow and market their own food.... Individual health and a sense of empowerment are enhanced when urban dwellers have access to and greater control over their own food system." In addition, community gardens are a powerful tool for creating good dietary practices among lowincome gardeners, as they provide an accessible source of affordable, culturally appropriate food (Brown \& Carter, 2003). In many areas where neighbors interact with each other only infrequently, gardens also provide an opportunity to build strong community ties (Teig, Amulya, Bardwell, Buchenau, Marshall, \& Litt, 2009). Empowering low-income communities to improve and maintain their community gardens can increase property values, improve community food security, offer job-skills development, provide safe outdoor spaces for play and interaction, and connect individuals and community groups to other communitysupporting organizations, all of which contribute to bringing communities out of poverty. However, without equitable, consistent access to those resources crucial to maintaining successful community green spaces, citizen involvement can be severely inhibited. One method of addressing this challenge is to develop a capacity-building program that enlists the resources of multiple organizations.

The Community Greening Resource Network (CGRN), based in Baltimore, Maryland, is one such program. CGRN was established in 2008 by a local nonprofit organization, the Parks \& People Foundation (Parks \& People), and the Baltimore City office of the University of Maryland Extension (Extension), and currently involves more than 26 partner organizations. CGRN aims to unite people of all ages and socioeconomic backgrounds through gardening and greening. In the course of its work, more than 20 new gardens have been developed in Baltimore City and more than 4,000 people are now benefiting from naturally grown food. In this case study we reflect on our
Established in 1984, Parks \& People hosts a wide range of recreational and educational programs, creating and sustaining beautiful, lively parks, and promoting a healthy natural environment for Baltimore. Parks \& People staff organize and assist community members in implementing greening and gardening projects in vacant lots, schoolyards, public housing projects, streetscapes, and other neighborhood open spaces.

The University of Maryland Extension (Extension) assists citizens in developing, implementing, and maintaining neighborhood beautification projects, community gardens, and vegetable gardens. Extension currently provides two programs in Baltimore that support community greening activities as a way to alleviate the consequences of poverty. Through its Master Gardener program, Extension provides technical support and education to urban gardeners through a "train the trainer" internship and mentorship program. The Gardening for Nutrition initiative builds gardens at schools, recreation centers, and senior centers, serving low-income communities by providing spaces for nutrition education, horticulture training, and local sources of fresh produce.

experience adapting Detroit's highly regarded community garden development program, the Garden Resource Program Collaborative, to the city of Baltimore, and offer recommendations for other communities considering a similar strategy.

\section{The Setting}

Over the past several decades, Baltimore has experienced steep population decline, resulting in rampant poverty, reduced access to healthy and affordable food, and an abundance of vacant properties. Baltimore City's current population is 636,919 (U.S. Census Bureau, 2009), a decline of $33 \%$ from its largest recorded population in 1950 (U.S. Census Bureau, 2010a). Approximately 22\% of Baltimore City's population lives in poverty, compared to just $8.3 \%$ in the state of Maryland as a whole (U.S. Census Bureau, 2009). Baltimore's 
high poverty rate is comparable to that of Pittsburgh and Detroit (U.S. Census Bureau, 2010b), two other postindustrial cities with which it is often compared.

In Baltimore, as in many other postindustrial cities, the phenomena of urban depopulation, food insecurity, and blight are linked. Over 13,000 vacant lots in Baltimore (Parks \& People Foundation, 2002a) are concentrated predominantly in neighborhoods where poverty rates are high. Within such neighborhoods, the challenges of poverty are compounded by weak housing markets and severely depressed physical, social, and economic conditions (Project Locus, 2005). Under such conditions, vacant lots and other open spaces often become agents of blight, further depressing property values as they become refuse-dumping sites and havens for illicit activity. In addition to blight, food insecurity is also directly tied to the prevalence of poverty. ${ }^{1}$ It is estimated that one in eight low-income families in Baltimore City is food insecure. Twenty-two percent of these families have children who do not eat adequate amounts of food (Black, 2008). In 2007-2008, 30.9\% of Baltimore's children were found to be living in poverty, and $73 \%$ received meals through the National School Lunch Program (Toldson, 2008).

On the other hand, Baltimore boasts a rich public history of protecting and supporting public green spaces. In 1904, Frederick Law Olmsted Jr. and John Charles Olmsted, sons of the famed landscape architect Frederick Law Olmsted, presented their plan for Baltimore's park system (Olmsted \& Olmsted, 1904). This far-reaching city plan envisioned a network of interconnected greenways throughout the city, including parks, playgrounds, stream buffers, tree-lined streets, and verdant residential districts. Such amenities reflected the philosophical belief prevalent at the time that all citizens, regardless of occupational or socioeco-

\footnotetext{
${ }^{1}$ Food insecurity is characterized by a limited ability to secure sufficient food (Holben, 2010) and has been defined as "limited or uncertain availability of nutritionally adequate and safe foods or limited or uncertain ability to acquire acceptable foods in socially acceptable ways" (Anderson, 1990, p. 1598).
}

nomic standing, should enjoy equitable access to public green space (Nicholson, 2004). Through their visionary plan for Baltimore's park system, the Olmsted brothers preserved the possibility for future development of community gardens and green spaces within the fabric of the city.

Indeed, over the years, many organizations around the city have worked to further this vision of a verdant, healthy, urban environment. In recent years, much effort has been targeted toward assisting citizen-led greening projects, ${ }^{2}$ including community gardens. However, such support is often limited by individual organizational capacity and geographic focus. Several gardens have failed as program funds ended, gardeners moved on, or resources became more difficult for residents to secure. Other threats to garden existence include loss of land due to redevelopment of city-owned parcels, soil contamination by lead and other toxins, and perceived lack of safety at garden sites.

\section{History of the Community Greening Resource Network}

Community-led greening projects existed in Baltimore well before the establishment of CGRN. A 2002 inventory and survey of communitymanaged open spaces in Baltimore (Parks \& People Foundation, 2002b) found evidence of 60 active citizen-led greening projects within the city. ${ }^{3}$ In a subsequent survey (Parks \& People Foundation, 2003), representatives of 50 such projects were asked to provide additional information about their gardens. Nearly half of survey respondents $(46 \%)$ characterized their greening projects as flower gardens or beautification projects, while a smaller percentage $(28 \%)$

\footnotetext{
${ }^{2}$ Such greening projects take a variety of forms, but are all characterized by citizen-initiated efforts to enhance, restore, or beautify urban landscapes through the installation of plants. Examples of greening projects include street-tree plantings, vacant-lot reclamation projects, curbside flowerpots, and community gardens.

${ }^{3}$ This inventory used a mixed-methods research approach consisting of site visits, telephone interviews, written surveys, and information-sharing among local organizations. As with any inventory effort, it is likely that not all existing project sites were captured.
} 
indicated that they were growing vegetables. These greening projects were located throughout Baltimore and were supported by a wide variety of organizations, including Parks \& People, Extension, local nonprofits, community associations, and the city Department of Recreation and Parks.

In addition to providing basic information about citizen-led gardening projects, both surveys offered insight into the challenges faced by community greeners. Participants in the 2002 inventory cited their top five challenges as: (1) lack of a committed volunteer base, (2) water scarcity, (3) lack of equipment, (4) infrastructure needs, and (5) training needs. In response to these findings, Parks \& People convened a forum of 70 urban gardeners to discuss the components of long-term project success. Attendees highlighted two such components: training opportunities, and material and infrastructural resources.

Having established baseline data regarding local greening projects and initiated a citywide dialogue with gardeners, staff at Parks \& People began seeking a means of providing sustainable long-term support for urban greening initiatives. In 2007, staff from Extension and Parks \& People attended the American Community Gardening Association annual conference in Boston and heard a presentation by the founder of Detroit's Garden Resource Program Collaborative (GRPC). The Detroit-based program was actively addressing many of the same needs and concerns expressed by Baltimore community gardeners. Moreover, numerous similarities between Detroit and Baltimore (e.g., socioeconomic characteristics, level of community gardening activity, high land vacancy rates, and pervasive food insecurity) suggested that the GRPC model could be successfully adapted to Baltimore. Parks \& People and Extension staff interviewed program representatives from Detroit and developed a proposal to adapt Detroit's model for use in Baltimore. This proposal was then presented to Baltimore stakeholders, including members of the city's greening community, garden advocates, nonprofit organizations, and resident groups. Response to the proposal was enthusiastic, and Parks \& People and Extension began making plans to develop and implement a garden resource network in Baltimore.

The Community Greening Resource Network (CGRN) was developed in fall 2008. A three-year plan was drafted and Parks \& People and Extension recruited an AmeriCorps*VISTA member to implement the plan. The VISTA member researched and communicated with several community garden support programs around the country. Continued contact with Detroit-based GRPC staff and stakeholders was very instrumental in informing CGRN development plans.

Additional momentum for establishing CGRN came from within Baltimore City government itself. In response to an October 2006 City Council resolution (City of Baltimore, 2006), the Baltimore City Council Task Force on Childhood Obesity was formed to assess the childhood obesity crisis. The resulting task force report drew attention to neighborhood-based food production as a possible means of improving childhood nutrition, and stated that "gardens should be developed on vacant city-owned lots and can be organized by neighborhood groups or non-profits" (Garrett, Gittelsohn, \& McGill, 2007). The Baltimore City Food Policy Task Force, jointly established by the Health Department and the Department of Planning in 2009, identifies means for Baltimoreans to access affordable healthy food and highlights community gardens as one such food source (City of Baltimore, 2009a).

\section{CGRN's Organizational Infrastructure}

\section{The Model: Detroit's Garden Resource Program Collaborative}

Detroit's Garden Resource Program Collaborative (GRPC) is a multitiered, decentralized, stakeholderdriven program that coordinates numerous state, city, neighborhood, and individual initiatives to combat poverty through community gardening. The GRPC supports over 500 family, school, and community gardens in Detroit and Highlandtown, Michigan, by providing resources and information that empower residents to grow, harvest, prepare, 
and preserve food (Atkinson, 2009). Through the large network, participating gardeners receive basic resources, including seeds and locally grown transplants, garden-based education, and opportunities to connect with other growers.

Detroit's program consists of a basic framework of opportunities for gardeners to access resources. Evaluation is integrated directly into every aspect of the program, allowing the quality and quantity of resources delivered to change based on evolving needs. Multiple entry points enable people to become involved in individualized capacities. Core partners include a local nonprofit and Michigan State University. A number of other organizations also contribute in a variety of ways.

\section{CGRN's Structure: A Partnership-Based Approach} The Community Greening Resource Network provides an organized system by which community gardeners and greeners can access educational and material resources. A written memorandum of understanding between Parks \& People and Extension lays the foundation for collaborative oversight of the program. Parks \& People houses CGRN at its headquarters and provides administrative and funding support; Extension provides access to research and evaluation tools, a skilled volunteer base, and connections to the University of Maryland and the state of Maryland. Through the first two years of the program's operation, 2008-2010, both organizations jointly supervised the CGRN coordinator, facilitated development of the CGRN advisory committee, promoted CGRN membership and programs to respective constituencies, and developed strategies for acquiring and distributing resources to CGRN members.

Over 26 partner organizations are involved in CGRN. Partners include community organizations, watershed protection groups, afterschool providers, for-profit and nonprofit greening groups, charitable foundations, city agencies such as the Office of Sustainability, and volunteer organizations. These groups support urban gardeners by providing education, funding, plant material, or tools. Each participating organization completes an annual partnership agreement with CGRN (see appendix A) detailing what the organization will contribute to the network over the course of the year. Their partnership in CGRN allows all CGRN members access to their resources; in return, their programs are advertised to CGRN's citywide audience. This collaboration among existing organizations has allowed project partners, in many cases, to better serve their constituencies. By amplifying partners' ability to reach intended audiences, and providing an array of opportunities for public participation, CGRN ensures that collaborating organizations derive institutional benefits from their affiliation with the network. The problem of "slippage," a disparity between policy and practice that occurs in community collaboration when individual organizations try to protect their interests (White \& Wehlage, 1995), is thereby avoided.

\section{Stakeholder-Led Advisory Committee}

Hardy (1998) states that an effective advisory committee should work within "mutually-agreed upon directions and boundaries." The 15 member CGRN advisory committee includes gardeners enrolled in the program, community leaders, and representatives from school gardening programs, greening organizations, and city agencies. The advisory committee meets quarterly, evaluating and modifying program practices in order to ensure that CGRN continues to meet the needs of lowincome community gardeners.

\section{Program Goals and Activities}

According to Ecotrust (2010), fair access to knowledge and resources, full participation in one's community, and self-determination in choosing a life path build local assets and result in reduced socioeconomic disparities. By supporting community gardens and encouraging citizen involvement in neighborhood revitalization, CGRN seeks to achieve such a transformation in Baltimore. Specifically, CGRN aims to effect longterm changes in the availability of healthy food sources and to increase self-reliance in Baltimore's population by promoting community gardens as a system for local food production, amplifying people's exposure to healthy food and gardening practices, and encouraging positive social inter- 
action between people of diverse backgrounds and interests. The program's goals, objectives, activities, and 2010 outcomes are summarized in figure 1 (next page).

CGRN membership is open to all members of the public. A tiered system of membership categories, with corresponding fees and benefits, enables members to select the level of involvement and the types of services that best suit their needs (see figure 2). Figure 3 displays CGRN's 2010 members by membership type. Grant funding has enabled CGRN to keep membership fees for community gardens very low; at present, a community garden pays $\$ 10.00$ in annual fees. This modest fee ensures that financial status does not serve as a barrier to participation. It also supports the philosophy of "crossfertilization" between gardens: when money is not a deciding factor, people may be more apt to share their resources, trade a skill, or volunteer time in exchange for another resource needed in the garden. Enrollment for all membership types is available year-round; the membership fee, a member enrollment form, and garden site photos are submitted annually. Gardens also agree to participate in an annual site visit through CGRN's Site Share program.

CGRN's members live and garden in diverse neighborhoods and vary in income level, ethnic background, educational attainment, gender, and age. Parks \& People and Extension constituencies were initially targeted as the primary beneficiaries of the program. The program was advertised to the constituencies of all partners, promotional brochures were distributed, staff attended many community meetings, and listings were posted with various newspapers. Figure 4 (page 10) displays a map of all CGRN Community Garden and Schoolyard Garden members in Baltimore City during 2010-2011. As the map demonstrates, member sites are distributed across the city. Many are located in neighborhoods characterized by limited access to forest patches and parks, suggesting that they are providing valuable green space in heavily urbanized areas.
Figure 2. CGRN Membership Categories, Annual Fees, and Benefits

\begin{tabular}{|c|c|c|}
\hline $\begin{array}{l}\text { Membership } \\
\text { Category }\end{array}$ & $\begin{array}{l}\text { Annual Fee } \\
\text { (USD) }\end{array}$ & Benefits \\
\hline \multirow[t]{4}{*}{ CGRN Advocate } & \multirow[t]{4}{*}{$\$ 5.00$} & $\begin{array}{l}\text { Subscription to quarterly newsletter, events } \\
\text { calendar, and monthly email blasts }\end{array}$ \\
\hline & & $\begin{array}{l}\text { Access to members-only areas of CGRN } \\
\text { website }\end{array}$ \\
\hline & & $\begin{array}{l}\text { Discounts on workshops and educational } \\
\text { programs }\end{array}$ \\
\hline & & Invitations to CGRN members-only events \\
\hline \multirow{2}{*}{$\begin{array}{l}\text { Private/Family } \\
\text { Garden }\end{array}$} & \multirow[t]{2}{*}{$\$ 15.00$} & All above benefits \\
\hline & & $\begin{array}{l}\text { Free plants and supplies at CGRN Give- } \\
\text { Away Days }\end{array}$ \\
\hline \multirow[t]{3}{*}{ Community Garden } & \multirow[t]{3}{*}{$\$ 10.00$} & All above benefits \\
\hline & & Free tool loans at Community Tool Banks \\
\hline & & Technical assistance and consultation \\
\hline \multirow[t]{2}{*}{ Schoolyard Garden } & \multirow[t]{2}{*}{$\$ 20.00$} & All above benefits \\
\hline & & $\begin{array}{l}\text { Curricular resources for schoolyard } \\
\text { gardening programs }\end{array}$ \\
\hline
\end{tabular}

Figure 3. 2010 CGRN Members by Membership Category

\begin{tabular}{lcc}
\hline Membership Category & 2010 Members & $\begin{array}{c}\text { Percentage of } \\
\text { Total Membership }\end{array}$ \\
\hline CGRN Advocate & 29 & $14.8 \%$ \\
\hline Private/Family Garden & 36 & $18.4 \%$ \\
\hline Community Garden & 93 & $47.4 \%$ \\
\hline Schoolyard Garden & 38 & $19.4 \%$ \\
\hline Total members & 196 & \\
\hline
\end{tabular}


Figure 1. CGRN Goals, Objectives, Program Activities, and Measurable Outcomes in 2010

\begin{tabular}{|c|c|c|c|}
\hline Overarching Goals & Program Objectives & Program Activities & 2010 Measurable Outcomes \\
\hline \multirow{4}{*}{$\begin{array}{l}\text { Increase access to } \\
\text { healthy food for } \\
\text { Baltimore residents, } \\
\text { prioritizing low-income } \\
\text { communities with } \\
\text { limited access to } \\
\text { sources of affordable, } \\
\text { healthy food. }\end{array}$} & \multirow{4}{*}{$\begin{array}{l}\text { Increase both the } \\
\text { number of community } \\
\text { gardens in Baltimore } \\
\text { City and the total } \\
\text { number of residents } \\
\text { involved in community } \\
\text { gardening. }\end{array}$} & $\begin{array}{l}\text { Assist city residents in developing } \\
\text { new community gardens. }\end{array}$ & $\begin{array}{l}2 \text { community gardens and } 1 \\
\text { schoolyard garden established with } \\
\text { CGRN assistance. }\end{array}$ \\
\hline & & \multirow{2}{*}{$\begin{array}{l}\text { Assist gardens with recruiting } \\
\text { new participants by publicizing } \\
\text { garden-based volunteer } \\
\text { opportunities, special events, } \\
\text { and news items. }\end{array}$} & $\begin{array}{l}10 \text { CGRN volunteer workdays } \\
\text { engaged } 270 \text { volunteers, providing } \\
550 \text { hours of service. }\end{array}$ \\
\hline & & & $\begin{array}{l}225 \text { events publicized through } \\
\text { quarterly newsletters and events } \\
\text { calendars, member website, and } \\
\text { monthly email blasts. }\end{array}$ \\
\hline & & $\begin{array}{l}\text { Inform constituents of grant } \\
\text { opportunities to fund citizen-led } \\
\text { greening and gardening projects. }\end{array}$ & $\begin{array}{l}\text { CGRN members applied for and } \\
\text { were awarded grants from Parks \& } \\
\text { People, Baltimore Community } \\
\text { Foundation, and Chesapeake Bay } \\
\text { Trust. }\end{array}$ \\
\hline \multirow{4}{*}{$\begin{array}{l}\text { Improve the quality of } \\
\text { life in Baltimore by } \\
\text { transforming vacant } \\
\text { lands into productive, } \\
\text { safe green spaces, } \\
\text { thereby enhancing the } \\
\text { city's green infra- } \\
\text { structure and reducing } \\
\text { urban blight. }\end{array}$} & \multirow{4}{*}{$\begin{array}{l}\text { Increase the quantity } \\
\text { and accessibility of } \\
\text { material and educa- } \\
\text { tional resources for } \\
\text { community gardeners, } \\
\text { thereby increasing the } \\
\text { capacity of existing } \\
\text { gardens and support- } \\
\text { ing the success of } \\
\text { newly established } \\
\text { projects. }\end{array}$} & $\begin{array}{l}\text { Distribute garden supplies to } \\
\text { CGRN members through regular } \\
\text { Give-Away Days. }\end{array}$ & $\begin{array}{l}\text { Approximately } 5,300 \text { seedlings, } \\
3,800 \text { seed packets, compost, } \\
\text { wood chips, and other supplies } \\
\text { distributed to } 100 \text { gardens. }\end{array}$ \\
\hline & & $\begin{array}{l}\text { Operate } 5 \text { Community Tool Banks } \\
\text { in geographically distributed areas } \\
\text { of Baltimore City, providing free } \\
\text { loans of hand tools for community } \\
\text { projects. }\end{array}$ & $\begin{array}{l}\text { Approximately } 50 \text { gardens } \\
\text { borrowed tools from Community } \\
\text { Tool Banks. }\end{array}$ \\
\hline & & $\begin{array}{l}\text { Host free or low-cost skill-building } \\
\text { workshops on gardening topics. }\end{array}$ & $\begin{array}{l}\text { Over } 100 \text { CGRN workshops held } \\
\text { over the course of the year. }\end{array}$ \\
\hline & & $\begin{array}{l}\text { Provide curricular materials for } \\
\text { teachers operating schoolyard } \\
\text { gardening programs. }\end{array}$ & $\begin{array}{l}38 \text { School Garden members used } \\
\text { CGRN resources. }\end{array}$ \\
\hline \multirow{5}{*}{$\begin{array}{l}\text { Build the capacity of } \\
\text { citizens to participate } \\
\text { actively in the } \\
\text { revitalization of urban } \\
\text { neighborhoods; build } \\
\text { sense of community } \\
\text { and shared purpose } \\
\text { among residents. }\end{array}$} & \multirow{5}{*}{$\begin{array}{l}\text { Engage CGRN partners } \\
\text { and members in all } \\
\text { aspects of program } \\
\text { management and } \\
\text { operations, contribu- } \\
\text { ting to long-term } \\
\text { program sustainability. }\end{array}$} & $\begin{array}{l}\text { Host quarterly advisory committee } \\
\text { meetings to guide policies, proce- } \\
\text { dures, and program offerings. }\end{array}$ & $\begin{array}{l}\text { Representatives of } 15 \text { partner } \\
\text { organizations participated in } 4 \\
\text { advisory committee meetings. }\end{array}$ \\
\hline & & $\begin{array}{l}\text { Host annual focus group sessions } \\
\text { to solicit evaluation from CGRN } \\
\text { members. }\end{array}$ & $\begin{array}{l}\text { Over } 40 \text { CGRN members attended } \\
4 \text { focus group sessions; their } \\
\text { evaluations were used to plan } \\
\text { programming for } 2011 \text {. }\end{array}$ \\
\hline & & $\begin{array}{l}\text { Host annual CGRN Summit to } \\
\text { engage partners and members in } \\
\text { strategic planning process. }\end{array}$ & $\begin{array}{l}20 \text { CGRN partners and members } \\
\text { attended CGRN Summit. }\end{array}$ \\
\hline & & $\begin{array}{l}\text { Through Site Share program, } \\
\text { engage members in visiting and } \\
\text { collecting data from other CGRN } \\
\text { gardens. }\end{array}$ & $\begin{array}{l}20 \text { volunteers completed site visits } \\
\text { of CGRN member sites. }\end{array}$ \\
\hline & & $\begin{array}{l}\text { Recognize and celebrate member } \\
\text { accomplishments at Parks \& } \\
\text { People's annual Community } \\
\text { Greening Celebration. }\end{array}$ & $\begin{array}{l}\text { Over } 100 \text { people attended the } \\
\text { Community Greening Celebration; } \\
15 \text { CGRN members and gardens } \\
\text { were nominated for or received } \\
\text { greening awards. }\end{array}$ \\
\hline
\end{tabular}


CGRN's support framework includes three basic components: materials (seeds, plants, hand tools, and other supplies), education (workshops and trainings), and connections (tours, celebrations, and meetings).

\section{Materials - Seeds, Plants, and Tools}

At least four times per year, CGRN hosts a GiveAway Day at a partner organization or garden. Representatives from member gardens pick up a share of plant materials and other supplies. Plants and seeds are donated from area nurseries and garden stores, other member gardens, youth programs, seed-donation programs, and from seedgrowing workshops. Businesses have been very supportive; in return for donations, they receive a tax deduction, advertising space, and the positive regard of donation recipients. One local business provided samples of a soil amendment product in 2010 and has since increased its customer base. These items are augmented by vegetable seedlings that CGRN arranges to grow specifically for distribution to members. Attendees are also encouraged to bring surplus plants and supplies to Give-Away Days to trade with other gardeners. In addition to providing gardeners with necessary resources, Give-Away Days are intended to nurture a culture of mutuality among members, building a sense of shared purpose and ultimately contributing to the long-term viability of the program.

CGRN also provides free loans of hand tools for members through its Community Tool Bank initiative. CGRN currently coordinates tool banks at five host organizations and is planning additional tool banks in underserved areas of Baltimore. Host organizations make their tools available for use by community-based greening groups; in exchange, CGRN provides a tool inventory, specialized training for tool bank managers, and administrative support. While many tools have been purchased through grant funding, others have been secured through in-kind donations from individuals and local businesses. To date, tool theft has been virtually nonexistent, demonstrating the effectiveness of CGRN's membership-based system. The tool sign-out system permits members to borrow tools free of charge for up to one week and requires that the borrower replace any broken or misplaced items. Due to maintenance costs and potential liability issues, power tools are not currently available for loan. However, CGRN is considering establishing a power-tool lending cooperative, whereby gardens with access to tillers and other power tools would make these implements available for use by other CGRN members. In exchange, borrowers would be required to provide reciprocal support to other gardens within the network.

\section{Education - Workshops and Trainings}

More than 15 organizations in Baltimore City provide education on gardening topics throughout the year. Monthly CGRN news blasts and a quarterly newsletter advertise upcoming citywide workshops, funding opportunities, member highlights, and other pertinent garden-related information. The quarterly shared calendar of events is color-coded by topic and month. By aggregating information about upcoming events and opportunities, CGRN provides an important service for Baltimore residents. Reminders are sent out regularly, and some members are telephoned on a regular basis to let them know about events on topics of special interest.

In addition to providing information to CGRN members, the shared events calendar serves two internal purposes. First, it enables participating organizations to coordinate their schedules so that event topics, locations, and times are distributed throughout the year, ensuring that offerings from different organizations complement, rather than compete against, one another. This strategy ensures that city residents are presented with a wide variety of educational opportunities and helps boost attendance at events. Second, having a shared events calendar enables participating organizations to determine gaps in programming. CGRN itself then develops programming to fill any gaps. Workshops and trainings are developed based on CGRN member feedback, and each new workshop is 
The seemingly intractable challenges of urban blight and pervasive food insecurity may be successfully combated by effective community revitalization efforts, like those employed by CGRN. For example, the Whitelock Community Farm (figure A) occupies a formerly vacant lot in Baltimore's Reservoir Hill neighborhood, while at the Montessori Public Charter School garden (figure B), vegetables, fruits, bees, and chickens are raised in a schoolyard setting.

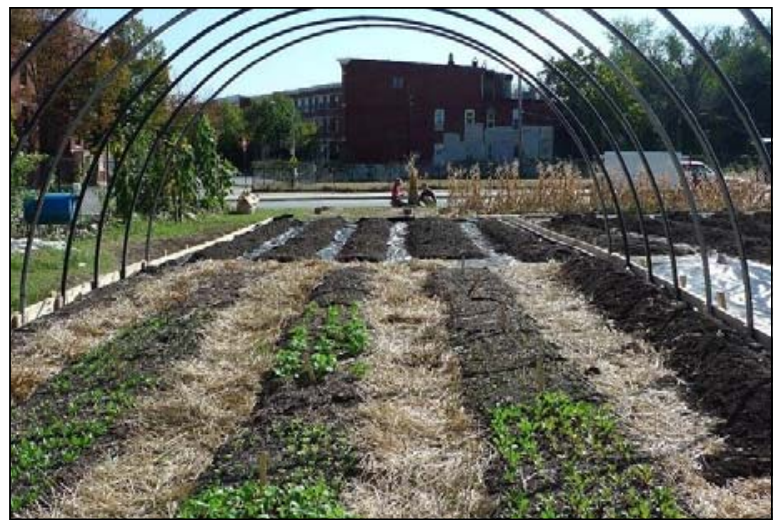

Figure A. Whitelock Community Farm was established in 2010 with the goal of providing fresh produce for residents in Baltimore's Reservoir Hill neighborhood. Photograph courtesy of Whitelock Community Farm.

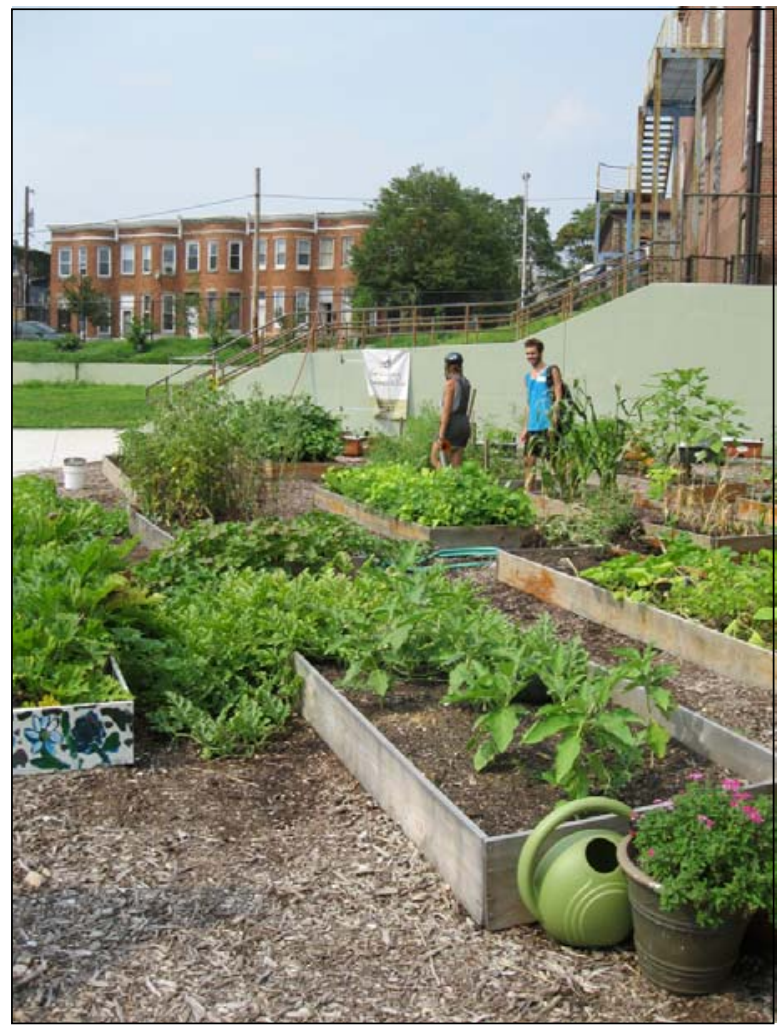

Figure B. The Baltimore Montessori Public Charter School has established a schoolyard garden that includes vegetable beds (pictured above), a fruit tree orchard, honey bee hives, and a flock of heritage chickens. Garden activities are linked to the school's educational curriculum, and students play an active role in garden management and maintenance.

Photograph courtesy of Parks \& People Foundation. taught and hosted by a different garden, partner organization, or volunteer. Past workshops have included Raised Bed Construction at the Remington Village Green, taught by an experienced gardener; Community Organizing 101 at a community church, taught by a regional nonprofit organization; and Growing in Greenhouses, presented by an Extension agent at a schoolyard garden site.

\section{Connections - Tours, Celebrations, and Meetings} CGRN provides members with many opportunities to share experiences and learn from each other. Volunteer Work Days, for example, occur one day per month during the growing season and rotate among different member gardens. Volunteers typically include members of other community gardens, interested citizens, school groups, and 
one-time volunteer groups in search of service opportunities. Celebrations provide opportunities for members to share, and be recognized for, their efforts. For example, the spring Urban Agriculture Gala features speakers, local musicians, and food grown in Baltimore City, and the fall Parks \& People Community Greening Celebration includes an awards ceremony to honor the achievements of Baltimore gardeners.
In order to foster further connections among members, CGRN maintains an interactive webbased map showing garden locations. When a user clicks on a garden location, additional information is presented, including site images, garden contact information, and visiting hours. This map also allows CGRN to schedule tours highlighting specific neighborhoods or types of gardens. Recently, it was used as a primary planning tool for the Charm City Garden Tour, which introduced participants to several community gardens in one subwatershed within Baltimore City. CGRN also publishes an annual membership directory that is distributed to all members and partners.

While CGRN's organizational partners provide many of the resources made available through the network, CGRN members themselves are frequently engaged as partners in the development and implementation of the program. Members contribute by participating in seasonal focus groups, conducting garden site visits, hosting workshops, volunteering at plant distribution days, and growing seedlings for other gardens. The CGRN Summit, an annual strategic planning meeting, engages all program constituents in evaluating the past year's progress and planning for the future.

\section{Ongoing Program Evaluation}

CGRN is designed to continually adapt and expand based on data and qualitative member feedback. Rather than offering a static 
portfolio of programs and resources, CGRN is flexible, providing diverse points of entry that allow participants to determine their own level of participation. Using a logic model (see appendix B), staff members from Parks \& People and Extension have developed measures and tools for program evaluation. Staff members from both organizations meet once per year to interpret data and determine whether objectives have been met. An extensive Microsoft Access database is used to track site and gardener information, volunteer hours, workshop attendance, and recommendations from feedback sessions. Additional data is collected through workshop evaluations and the CGRN membership enrollment form, which provides valuable information about member characteristics.

This information has been made available to individuals and organizations researching food security, urban revitalization, and other relevant topics. CGRN data was used by city government staff to define vacant-lot redevelopment policies and assist with citywide sustainability goals (City of Baltimore, 2009b). The Johns Hopkins University's Center for a Livable Future, a research center focused on public health matters, has overlaid community garden data with health statistics to direct funds to the neediest neighborhoods. Data collected by CGRN has played a role in preventing the sale and redevelopment of parcels occupied by community gardens. ${ }^{4}$ CGRN has also been discussed and cited in a number of recent masters' theses. $^{5}$

\footnotetext{
${ }^{4}$ For example, CGRN and its partners assisted members of the Ash Street Community Garden to successfully retain access to two adjacent parcels that, though legally under the garden's care through Baltimore's Adopt-a-Lot program, had been mistakenly made available for purchase by developers. Since securing long-term access to these parcels, the Ash Street Community Garden has been able to significantly expand its activities. In addition to providing both individual and cooperatively run garden plots, the group now hosts workshops and special events and has become a community hub.

${ }^{5}$ For example, in: Corrigan, M. P. (2010). Growing what you eat: Developing community gardens and improving food security. Thesis presented to the faculty of College of Arts and Sciences of Ohio University.
}

At this early juncture, it is not possible to know whether the program will be successful over the long term. At present, however, only three years since CGRN was initiated, we are meeting and in many cases far exceeding our initial goals. Between 2009 and 2010, community garden membership in CGRN increased by $38.8 \%$ and schoolyard garden membership increased by 100\%. Resource distribution has kept pace with membership numbers. For example, participation in monthly Volunteer Work Days increased by 95\% from 2009 to 2010, enabling CGRN to provide greater labor support for garden projects. The volume of plants and supplies distributed at Give-Away Days, the number of tools loaned through Community Tool Banks, and the number and range of CGRNsponsored workshops and special events also increased during this period.

Though we may have to wait several years for conclusive data to demonstrate the connection between CGRN's work and reduced poverty levels or health impacts, gardeners and other residents are nevertheless benefiting from the collaborative efforts of this program. Each year, representatives from member gardens have actively participated in feedback sessions and garden site visits. At the 2009 member focus groups, one participant expressed appreciation at being "part of a large, useful, and active network and community." Martha Barss, a CGRN member who manages a vegetable gardening program at a low-income school, said, "We are definitely benefitting from belonging to CGRN. Not only are the tools a great benefit...but we also connect to others in the community who support the same initiatives we do." The Unity Community Garden, established with CGRN's assistance in a neighborhood whose three public schools receive Title 1 services (Baltimore City Public Schools, 2009), has reported increased homeownership in its neighborhood. As a member of the Unity Community Garden noted, "A couple came up to me and said that they are seriously considering buying a house on the block even though there are several abandoned properties, because they saw a garden work day and look forward to living across from the green space." 


\section{Securing Long-Term Membership}

Each year, CGRN members are presented with additional ways to become involved in and benefit from the program, encouraging membership renewal. For example, second-year members may apply to work with a skilled group of volunteers who assist with garden infrastructure. Third-year members may apply for partial scholarships towards advanced horticultural training courses. These opportunities, as well as continued access to CGRN's basic array of program features, build the capacity of long-term members, thereby contributing to the stability and success of individual greening projects. CGRN itself also derives benefits from the long-term participation of its members. Long-term members frequently serve as unofficial program ambassadors, promoting CGRN to potential participants as well as to the general public. As members gain gardening expertise, they also give back to CGRN by teaching workshops and mentoring newer gardeners. Finally, CGRN is able to collect longitudinal data on its long-term members, enabling staff to evaluate the program's impact and develop an accurate picture of community gardening in Baltimore.

\section{Securing Long-Term Staff Funding}

Thus far, CGRN has subsisted on a relatively modest operating budget (figure 5), capitalizing on existing resources and securing additional resources through donations. The key to CGRN's initial development has been the recruitment of a series of three AmeriCorps*VISTA volunteers, each of whom has served a year-long term as full-time program coordinator. The CGRN coordinator is responsible for all aspects of program administration, including
Figure 5. CGRN Summary Program Budget, 2009-2011

\begin{tabular}{lrrr}
\hline & 2009 & 2010 & 2011 \\
\hline Income & & & \\
\hline Nongovernment Grants & $\$ 8,333$ & $\$ 10,000$ & $\$ 18,155$ \\
\hline Government Grants & $\$ 19,467$ & $\$ 19,467$ & $\$ 12,978$ \\
\hline In-Kind Contributions & $\$ 7,000$ & $\$ 7,000$ & $\$ 10,000$ \\
\hline Program Fees & $\$ 1,500$ & $\$ 2,000$ & $\$ 2,500$ \\
\hline Special Event Revenue (net) & $\$ 200$ & $\$ 200$ & $\$ 200$ \\
\hline Total Income & $\$ 36,500$ & $\$ 38,667$ & $\$ 43,833$ \\
\hline Expenses & $\$ 27,466$ & $\$ 27,466$ & $\$ 30,000$ \\
\hline Salaries & $\$ 6,084$ & $\$ 6,084$ & $\$ 6,645$ \\
\hline Benefits & $\$ 2,600$ & $\$ 4,567$ & $\$ 6,438$ \\
\hline Program Expenses & $\$ 150$ & $\$ 250$ & $\$ 350$ \\
\hline Publicity, Fundraising and Printing & $\$ 200$ & $\$ 300$ & $\$ 400$ \\
\hline Travel & & $\$ 38,667$ & $\$ 43,833$ \\
\hline Total Expenses & & &
\end{tabular}

membership coordination, database management, Community Tool Bank oversight, volunteer training and recruitment, special event coordination, and fundraising. Without the dedicated service of our AmeriCorps*VISTA volunteers, initial development of CGRN would simply not have been possible.

Continued staff funding is necessary, however, to ensure future program operations. Detroit's program is partially supported by its host organization, The Greening of Detroit, and also by the AmeriCorps State program and federal grants. Many of CGRN's programmatic components feasibly could be funded by local sources. However, such local grants are often not large enough to support staff time and the myriad overhead costs associated with program administration. As is true for many nascent nonprofit initiatives, staff funding currently presents one of CGRN's largest challenges.

Future Directions and Additional Partners As participation in CGRN grows, program staff, 
members, and collaborators are actively seeking opportunities to expand offerings and develop new partnerships. Accurate information about soil fertility and toxicity, community leadership training, and GPS-coordinated garden maps are member-generated ideas for future expansion of the program.

Developing our partnership with the University of Maryland, United States Forest Service, United States Geological Survey, and the Baltimore Ecosystem Study will give us access to detailed soil and other environmental information. Lead and arsenic levels in urban gardens are a source of concern, and with accurate knowledge about the safety of each garden location, we can prevent unnecessary risks. Partnerships with community resource centers will allow us to schedule leadership trainings. Developing effective leaders in each of Baltimore's neighborhoods will help prevent garden collapse and has been shown to increase the overall capacity of a neighborhood. One of CGRN's current partners, Baltimore Green Space, is spearheading a community action program to map Baltimore's gardens and link them to lot and parcel numbers, providing information that will aid us in protecting gardens from redevelopment. Also planned for 2011 is a welcoming committee to introduce new members to CGRN. These and other ideas for future directions were generated and discussed at the annual focus groups and strategic-planning meeting.

Furthermore, far-reaching changes to Baltimore City's zoning code set to take effect in 2011 will permit community gardens and urban agriculture projects in most areas and will allow on-site farm stands for the first time in the city's history (City of Baltimore, 2010). These zoning changes have the potential to bring community-grown fruits and vegetables to an unprecedented number of residents in Baltimore's low-income communities.

Finally, CGRN hopes to contribute to the establishment of successful garden resource networks in other cities. Staff from Grassroots Gardens of Buffalo and Brooklyn Greenbridge, both in New York state, have sought advice recently in replicating "CGRN on a smaller scale" and working with their local Extension coordinator and Master Gardener programs.

\section{Recommendations}

Based on our experience in implementing the CGRN program, the authors would like to offer the following recommendations for groups interested in establishing similar resource networks:

\section{Evaluate the level of community need and} interest. Convene a meeting of community members and leaders to discuss current needs and identify gaps in existing support for citizenled greening initiatives. Use the data generated by these conversations to identify the role a resource network might play in meeting current needs. In addition to helping you plan your program's offerings, a firm statement of need, supported by measurable data, is an essential aid in securing financial support.

\section{Garner meaningful support from project} partners and clearly define all partners' roles. Engage nonprofit organizations, government agencies, private businesses, educational institutions, and other service providers in your area to discuss how existing services could be better coordinated in response to identified community need. Establish what resources each partner will make available through the resource network, and secure written partnership agreements or memoranda of understanding from primary partners.

\section{Establish shared governance and program} oversight. Establish a program advisory committee and invite partners and community members to play an active role in guiding program policies, procedures, and overarching goals. Hold advisory committee meetings in a convenient location and invite partners to host certain meetings at their own headquarters. To the extent possible, decentralize procedures so program activities are not reliant on one organization. Solicit the input of the program's general membership through annual focus 
group sessions, planning meetings, and membership surveys.

\section{Take advantage of opportunities to secure} staffing support. Establishing and administering a resource network takes time, and funding for staff salary can be difficult to secure. The AmeriCorps*VISTA program, operated by the Corporation for National and Community Service, places young adults in year-long, fulltime positions at nonprofit agencies around the country. VISTA volunteers can play a major role in establishing new initiatives, and your organization may be eligible to host up to three VISTA volunteers. ${ }^{6}$

\section{Call on the expertise of others with experi-} ence in implementing such programs. Staff members from the Greening of Detroit provided invaluable counsel during the early stages of CGRN's establishment, as did representatives of the Community Food Security Coalition. We encourage you to seek the guidance of those who have gone before you; the value of this advice cannot be overstated.

6. Determine baseline indicators of poverty and health with which to evaluate the program. Collecting accurate evaluation standards and linking your program's goals to measurable outcomes can be a great benefit in securing support from local government and financial sources. It might be helpful to partner with a local university or public research center to develop these indicators and to help measure the effect and impact of the program over the long term.

\section{Conclusion}

CGRN is an example of a stakeholder-driven coordinating program that identifies the needs of community gardeners and provides access to resources available from organizations, businesses, and peers within the gardening community. By

${ }^{6}$ For more information on the AmeriCorps*VISTA program, see http://www.americorps.gov/for_organizations/apply/ vista.asp doing so, CGRN provides comprehensive, citywide support for community gardeners and empowers residents to play an active role in urban revitalization. Key program components include partner and member relationships; materials, education, and connections provided for and between gardeners; and ongoing program evaluation. By building citizen capacity to effect positive change, programs such as CGRN may enable cities to become beautiful, green, safe places where all residents enjoy the environmental, socioeconomic, and health benefits of a thriving green infrastructure.

\section{Acknowledgements}

Overwhelming appreciation, the deepest admiration, and the longest-lasting ovations belong to Ashley Atkinson, Chrissa Carlson, Katie Dix, Josue Lopez, Sarah Ritter, Kari Smith, and Lindsay Turpin, and many other staff from Parks \& People and Extension, as well as all those who are part of the Community Greening Resource Network, and all that has been and will be created by Baltimore's dedicated community gardeners. 


\section{Appendix A. Partner Agreement Form for the Community Greening Resource Network}

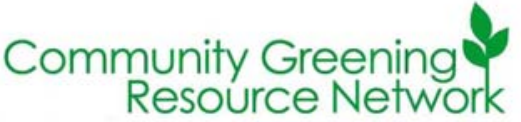

MAIVERSITY OF $\quad$ PARKS\&

E X T E N S I O N

Solutions in your community

\section{Partner Agreement Form}

The Community Greening Resource Network (CGRN) brings together the resources of many organizations to more effectively and efficiently support Baltimore's community greeners. This Partnership Agreement Form is valid for one calendar year and will be reviewed annually.

\section{CGRN Goals:}

- Promote urban agriculture and greening in Baltimore as a tool for revitalizing communities and increasing access to healthy food and opportunities for outdoor recreation;

- Create an organized program through which community gardeners are provided with access to information, training, and material resources;

- Coordinate existing efforts of greening organizations to advertise and increase participation in educational activities:

- Increase the quantity of material resources available to community greening stewards;

- Promote the successful management of green spaces through regular site visits and provision of training opportunities; and

- Recognize and reward Baltimore's urban gardens for their commitment and dedication to their communities.

I, , on behalf of my organization

agree that my organization will receive the following from CGRN:

Space on the monthly calendar, distributed to

all members, for relevant programming

Opportunities to have my events hosted at

CGRN sites

Name/logo on CGRN documents and at

CGRN events
Direct input in CGRN's policies and procedures through the Advisory Committee Oother:

Other:

Other:

In return, my organization agrees to provide or contribute the following to CGRN:

Participate in regular calendar setting meetings and add events to the calendar

$\square$ Manage Community Tool Banks and facilitate tool rentals

Complete Site Shares for new members

Solicit and work with CGRN sponsors

Solicit new CGRN partners

Provide volunteers for program components
Use the CGRN sign-in sheet and evaluation form at events

Provide space for workshops

Distribute CGRN membership forms and encourage membership

Donate plant material to the give-away days Other:

Oother:

Name:

Organization

Signature/ Date 


\section{Appendix B. Logic Model for the Community Greening Resource Network}

\begin{tabular}{|c|c|c|c|c|c|c|}
\hline Situation & $\Longrightarrow$ & Activities & Outputs & & Outcomes & \\
\hline $\begin{array}{l}\text { Access to education } \\
\text { and resources } \\
\text { - Insufficient } \\
\text { access to } \\
\text { necessary } \\
\text { gardening } \\
\text { resources } \\
\text { - Educational } \\
\text { opportunities } \\
\text { inaccessible } \\
\text { Public health } \\
\text { - High food costs } \\
\text { High quality food } \\
\text { not sold in low- } \\
\text { income neighbor- } \\
\text { hoods } \\
\text { - High risk of diet- } \\
\text { related chronic } \\
\text { disease among } \\
\text { low-income } \\
\text { residents } \\
\text { Increasing rates } \\
\text { of obesity among } \\
\text { low-income } \\
\text { residents } \\
\text { Quality of life } \\
\text { Vacant land } \\
\text { creates blight } \\
\text { Insufficient green } \\
\text { infrastructure in } \\
\text { urban areas } \\
\text { Limited oppor- } \\
\text { tunities for neigh- } \\
\text { bors to work } \\
\text { together }\end{array}$ & $\begin{array}{l}\text { For all objectives } \\
\text { - Understanding of } \\
\text { requirements for } \\
\text { successful urban } \\
\text { food gardening } \\
\text { - Infrastructure } \\
\text { (platform for } \\
\text { interorganizational } \\
\text { communication } \\
\text { and coordination, } \\
\text { easily accessible } \\
\text { material, and } \\
\text { information- } \\
\text { distribution sites) } \\
\text { - Staff time } \\
\text { - Federal, state, and } \\
\text { private funds } \\
\text { - Staff and } \\
\text { community } \\
\text { expertise } \\
\text { - Resources } \\
\text { contributed by } \\
\text { businesses and } \\
\text { organizations } \\
\text { (plants, seeds, } \\
\text { tools, volunteer } \\
\text { time) } \\
\text { - Stakeholder-led } \\
\text { program evalua- } \\
\text { tion and input } \\
\end{array}$ & $\begin{array}{l}\text { Access to education and } \\
\text { resources } \\
\text { - Coordinate and provide mate- } \\
\text { rial and educational re- } \\
\text { sources for urban gardeners } \\
\text { - Provide training and opportu- } \\
\text { nities for low-income } \\
\text { gardeners } \\
\text { - Involve stakeholders in pro- } \\
\text { gram operations, administra- } \\
\text { tion, and evaluation } \\
\text { Public health } \\
\text { - Make locally grown produce } \\
\text { available to low-income } \\
\text { residents via community and } \\
\text { schoolyard gardens } \\
\text { Quality of life } \\
\text { - Encourage transformation of } \\
\text { blighted vacant lands into } \\
\text { productive, safe, and acces- } \\
\text { sible urban green spaces } \\
\text { - Provide opportunities for } \\
\text { residents to work together to } \\
\text { revitalize communities } \\
\text { Who we reach } \\
\text { - Low-income gardeners } \\
\text { - Underserved neighborhoods } \\
\text { - Baltimore City consumers } \\
\text { - Volunteers } \\
\text { - Educators } \\
\text { - Fity government, nonprofit } \\
\text { and community organizations, } \\
\text { public agencies } \\
\text { funders } \\
\text { - Private businesses }\end{array}$ & $\begin{array}{l}\text { Access to education } \\
\text { and resources } \\
\text { - Seed and plant } \\
\text { Give-Away Days } \\
\text { - Community Tool } \\
\text { Banks } \\
\text { - Public calendar of } \\
\text { workshops and } \\
\text { events offered } \\
\text { citywide } \\
\text { - Regular member } \\
\text { communication with } \\
\text { opportunities, } \\
\text { information, and } \\
\text { announcements } \\
\text { Public health } \\
\text { - Educational pro- } \\
\text { gramming focused } \\
\text { on gardening and } \\
\text { nutrition } \\
\text { - Material and tech- } \\
\text { nical support for } \\
\text { urban food garden- } \\
\text { ing activities } \\
\text { Quality of life } \\
\text { - Material and tech- } \\
\text { nical support for } \\
\text { expansion of green } \\
\text { infrastructure } \\
\text { - Regular volunteer } \\
\text { work days } \\
\text { - Opportunities for } \\
\text { positive social } \\
\text { interaction } \\
\end{array}$ & $\begin{array}{l}\text { Knowledge } \\
\text { Access to education } \\
\text { and resources } \\
\text { - How to find plants, } \\
\text { tools, and } \\
\text { workshops } \\
\text { - Low-cost methods } \\
\text { for growing food } \\
\text { Public health } \\
\text { - Increased } \\
\text { knowledge of } \\
\text { positive life } \\
\text { choices } \\
\text { - New healthy food } \\
\text { choices } \\
\text { Quality of life } \\
\text { - Improved } \\
\text { gardening skills } \\
\text { - How to gain } \\
\text { access to vacant } \\
\text { land for } \\
\text { community use } \\
\text { - How to connect } \\
\text { with other } \\
\text { gardeners }\end{array}$ & $\begin{array}{l}\text { Actions } \\
\text { Access to education } \\
\text { and resources } \\
\text { - Adopt new skills } \\
\text { and apply } \\
\text { knowledge } \\
\text { - Donate time } \\
\text { working in other } \\
\text { community } \\
\text { gardens and } \\
\text { contribute to } \\
\text { program research } \\
\text { - Participate in } \\
\text { resource-sharing } \\
\text { Public health } \\
\text { - Involve low-income } \\
\text { community } \\
\text { members new to } \\
\text { gardening } \\
\text { - Choose and } \\
\text { consume healthy, } \\
\text { locally grown } \\
\text { produce } \\
\text { - Encourage healthy } \\
\text { food choices } \\
\text { among others } \\
\text { Quality of life } \\
\text { - Active stewardship } \\
\text { - Start new gardens } \\
\text { - Community } \\
\text { engagement } \\
\text { - Share garden } \\
\text { experiences }\end{array}$ & $\begin{array}{l}\text { Conditions } \\
\text { Access to education } \\
\text { and resources } \\
\text { - Higher productivity of } \\
\text { urban food gardens } \\
\text { - Increased } \\
\text { opportunities for low- } \\
\text { income communities } \\
\text { to grow fresh food } \\
\text { - Alleviation of poverty } \\
\text { Public health } \\
\text { - Reduced obesity and } \\
\text { improved nutrition } \\
\text { and health } \\
\text { - Healthier, more } \\
\text { accessible food } \\
\text { supply } \\
\text { Quality of life } \\
\text { - Greener environment } \\
\text { Better quality of life } \\
\text { in urban } \\
\text { communities } \\
\text { Opportunities for } \\
\text { underserved } \\
\text { residents to } \\
\text { contribute } \\
\text { significantly in } \\
\text { building public green } \\
\text { spaces }\end{array}$ \\
\hline
\end{tabular}




\section{References}

Anderson, S. A. (1990). The 1990 Life Sciences Research Office Report on Nutritional Assessment. Journal of Nutrition, 102, 1559-1660.

Atkinson, A. (2009). Garden Resource Program Collaborative. Retrieved from http://www.detroit agriculture.org/garden_resource_program.html

Baltimore City Public Schools. (2009). Title 1 Schools for 2009-2010. Retrieved from http://www.baltimore cityschools.org/Departments/Chief_Academic_Of ficer/PDF/TitleISchoolsSY0910 Web.pdf

Black, M. M. (2008). Food Security: Ensuring the Health of Baltimore's Babies. Baltimore, MD: Growth and Nutrition Division of the Department of Pediatrics at the University of Maryland School of Medicine.

Brown, K. H., \& Carter, A. (2003). Urban agriculture and community food security in the United States: Farming from the city center to the urban fringe. Retrieved from http://www.foodsecurity.org/PrimerCFSCUAC. pdf

City of Baltimore. (2006). City council resolution 06-0230R. Retrieved from http://legistar.baltimorecitycouncil. $\mathrm{com} /$ detailreport $/$ ?key $=3173$

City of Baltimore. (2009a). Department of planning: Baltimore City's food policy task force. Retrieved from http://www.baltimorecity.gov/Government/Agen ciesDepartments/Planning/FoodPolicyTaskForce. aspx

City of Baltimore. (2009b). The Baltimore Sustainability Plan. Retrieved from http://www.baltimorecity. gov/LinkClick.aspx? fileticket=DtRcjL $\% 2 \mathrm{fIBcE} \% 3$ d\&tabid $=128$

City of Baltimore. (2010). Baltimore Zoning Code: Draft 1.0. Retrieved from http://www.transformbaltimore. net/portal/zoning-apr-draft?tab=files

Ecotrust. (2010). Reliable prosperity. Retrieved from http://www.reliableprosperity.net/social_equity. html

Garrett, A. Y., Gittelsohn, J., \& McGill, A. (2007). Report of the Baltimore City Council Task Force on Childhood Obesity. Baltimore, MD: Baltimore City Council Task Force on Childhood Obesity.

Hardy, C., \& Phillips, N. (1998). Strategies of engagement: Lessons from the critical examination of collaboration and conflict in an interorganizational domain. Organization Science, 9(2), 217-230. doi:10.1287/orsc.9.2.217

Holben, D. (2010). The concept and definition of hunger and its relationship to food insecurity. Journal of the American Dietetic Association, 110(9), 1368-1377. doi:10.1016/j.jada.2010.07.015
Hunger Task Force. (2008). Retrieved from http://www.hungertaskforce.org

Nicholson, C. (2004). Elegance and grass roots: The neglected philosophy of Frederick Law Olmsted. Transactions of the Charles S. Peirce Society, 40(2).

Olmsted, F. L., \& Olmsted, J. C. (1904). Report upon the development of public grounds for Greater Baltimore. Baltimore, MD: The Lord Baltimore Press.

Parks \& People Foundation. (2002a). Neighborhood open space management: A report on the V acant Lot Restoration Program in Baltimore. Retrieved from http://www. parksandpeople.org/publications/special reports/ VLRP.pdf

Parks \& People Foundation. (2002b). Community Garden Inventory. Unpublished research; contact info@parksandpeople.org to receive manuscript.

Parks \& People Foundation. (2003). Neighborhood open space management: Community greening survey and land trust strategies for Baltimore City. Retrieved from http://www.parksandpeople.org/files/resources/ 2577 Neighborhood $\% 20$ Open $\% 20$ Space $\% 20$ Management.pdf

Project Locus. (2005). Lively Stone Church of God in Christ and Community Center project description. Retrieved from http://www.projectlocus.org/locus stone \%2001.htm

Teig, E., Amulya, J. , Bardwell, L., Buchenau, M., Marshall, J. A., \& Litt, J. S. (2009). Collective efficacy in Denver, Colorado: Strengthening neighborhoods and health through community gardens. Health \& Place, 15(4), 1115-1122. doi:10.1016/j.healthplace.2009.06.003

Toldson, I. A. (2008). Breaking barriers: Plotting the path to academic success for school-age African-American males. Washington, DC: Congressional Black Caucus Foundation, Inc.

U. S. Bureau of the Census. (2009). State and County QuickFacts: Baltimore City, Maryland. Retrieved from http://quickfacts.census.gov/qfd/states/24/24510. $\underline{\mathrm{html}}$

U. S. Bureau of the Census. (2010a). 1960 census of population: Population summaries. Retrieved from http://www2.census.gov/prod2/decennial/ documents/41983291.pdf

U. S. Bureau of the Census. (2010b). State and County QuickFacts. Retrieved from http://quickfacts. census.gov/qfd/states.html

White, J. A., \& Wehlage, G. (1995). Community collaboration: If it is such a good idea, why is it so hard to do? Educational Evaluation and Policy Analysis, 17(1), 23-38. 
Journal of Agriculture, Food Systems, and Community Development ISSN: 2152-0801 online

www.AgDevJournal.com 